\title{
Breeding Bird Relationships to Landscape Metrics in Coastal Plain Georgia
}

\author{
Brice B. Hanberry, ${ }^{1,2}$ Stephen Demarais, ${ }^{1}$ and Jeanne C. Jones ${ }^{1}$ \\ ${ }^{1}$ Forest and Wildlife Research Center, Department of Wildlife and Fisheries, P.O. Box 9690, Mississippi State, MS 39762, USA \\ ${ }^{2}$ School of Natural Resources, Department of Forestry, University of Missouri-Columbia, Columbia, MO 65211, USA
}

Correspondence should be addressed to Brice B. Hanberry, hanberryb@missouri.edu

Received 7 December 2011; Accepted 22 January 2012

Academic Editor: C. Carcaillet

Copyright ( 2012 Brice B. Hanberry et al. This is an open access article distributed under the Creative Commons Attribution License, which permits unrestricted use, distribution, and reproduction in any medium, provided the original work is properly cited.

\begin{abstract}
Some avian species in the southeastern United States are declining, and population decreases may arise from changes in vegetation type area or structural condition. Our objective was to compare abundance of conservation priority bird species with landscape variables. We found, even in the highly forested Coastal Plain of Georgia, that areal extent and core area of cover types were related to abundance for certain bird species. Acadian flycatcher and field sparrow had models that incorporated positive area variables. Downy woodpecker, northern parula, orchard oriole, prairie warbler, and summer tanager had models that included positive area and edge associations with varying scales and vegetation types. Edge appeared in models for red-bellied woodpecker, blue jay, and brown-headed cowbird. More than half of all species did not have models that met prediction thresholds. Systematic assessment of area requirements for declining species provides information for management, conservation, and research.
\end{abstract}

\section{Introduction}

Populations of certain bird species in the southeastern United States are declining, particularly disturbance-dependent species associated with grasslands, shrublands, and open forests [1]. Population trends may arise from land use changes in vegetation type area or structural condition. Stand elements, including vegetation composition and structure, can affect a variety of bird species, such as cavity nesters that require older trees or early successional species that need an open canopy and midstory. Thus, availability of standlevel structural elements may also be related, cumulatively at the landscape scale, to abundance of some declining bird species.

Most bird-landscape studies have taken place outside of the Southeast. Compared to regions with forests fragmented by agriculture and urbanization, Coastal Plain landscape research on breeding birds has been equivocal, perhaps because many patches of one forest type or stage are enclosed within forest of another type or stage $[2,3]$. Such studies include Krementz and Christie [4], who detected no effect of clearcut size on species richness or juvenile to adult ratios in birds captured in mist nets. Aquilani and Brewer [5] determined that wood thrush (see Table 2 for scientific names) nest success was greatest in large fragments of vegetation types and least near clearcut edges, primarily due to varying predation levels. Edge increased nest predation and negatively affected indigo bunting nesting success [6], but edge did not depress Acadian flycatcher nest survival [7]. In investigations of bottomland hardwood widths, Hodges and Krementz [8] and Kilgo et al. [9] found that species richness increased with riparian width.

Given that there is incomplete regional knowledge about avian habitat requirements, exploratory models can contribute valuable information about landscape metrics associated with avian presence for conservation management and research. Habitat selection involves multiple scales, or at least changes depending on observation scale, and may vary by region $[10,11]$. Regional habitat modeling at different scales for birds that are declining may help establish area sensitivity classifications. Our objective was to identify land class variables at varying scales that potentially predict abundance of priority avian species in Coastal Plain Georgia. 


\section{Methods}

2.1. Study Area. Southeastern Georgia is in the Coastal Plain, a low, flat physiographic region of the southeastern United States. Coastal Plain vegetation consists of upland forests interspersed with wetlands and poorly drained flatwoods. Land use consists of row crop agriculture and intensively managed pine forest, with urbanization along the coast [12]. In 1999, Georgia had 9.5 million ha of timberlands, $60-65 \%$ of the State's total area, including 2.5 million ha in planted pine and 1.85 million ha in natural pine [13]. Forested areas are young; 3.3 million ha are in the seedling sapling stage (less than $12.7 \mathrm{~cm} \mathrm{dbh;} \mathrm{[13]).} \mathrm{Disturbance} \mathrm{agents} \mathrm{include}$ fire, hurricanes, tornadoes, floods, and ice storms.

2.2. Data Sets. We combined the North American Breeding Bird Survey (BBS; [14]), coordinated by USGS Patuxent Wildlife Research Center, with the Georgia Gap Analysis land cover grid (GA-GAP; Kramer et al. 2003 [12]), to correlate bird species abundance with spatial metrics. Breeding Bird Survey routes are approximately $40 \mathrm{~km}$ long and consist of 50 points that are $0.8 \mathrm{~km}$ apart. Volunteers record birds within a $400 \mathrm{~m}$ radius during 3 minutes at each point. One bias of BBS is that surveys occur alongside roads. However, there are roads throughout Georgia, where roadless areas may be limited [15]. The GA-GAP classified 30-meter resolution Landsat Thematic Mapper satellite imagery, using 1996-1998 imagery. There are 44 land cover classes with an overall accuracy of $75.5 \%$. The satellite imagery occurred before the accuracy assessment, which contributed to error rate.

From the BBS database, we selected all routes in Georgia's Coastal Plain and Flatwoods with 3 survey years under approved conditions during 1995 to 1999 ( $n=27$ routes). We divided the routes into 5,10 -stop partial routes about $8 \mathrm{~km}$ in length and selected the straightest (i.e., covering greatest area) partial route from each end (i.e., not the middle partial route). We placed buffered extents of $0.5,1,2$, and 4 $\mathrm{km}$ around each partial route. We eliminated 2 partial routes, due to overlap at the $4 \mathrm{~km}$ buffer extent, leaving 52 route segments. For all these operations, we used ArcGIS (ESRI, version 9.0, Redlands, CA, USA).

We retained, with some reclassification, 8 GA-GAP land cover classes for analysis: (1) hardwood forests (2) hydric hardwoods (bottomland hardwood, cypress-gum swamp, evergreen forested wetland), (3) clearcut (recent clearcuts, sparse vegetation, and other early successional areas, (4) pasture/hay, (5) mixed forest, (6) managed pine (loblolly shortleaf, loblolly slash), (7) longleaf pine, and (8) shrub (sandhill, shrub wetland). We clipped the reclassified grid using the buffered partial route shapes, creating grids of each partial route at 4 buffer distances.

We used FRAGSTATS [16] to compute 7 spatial metrics for each class type. Metrics for modeling included area (AREA; mean patch area, depends on patch size and number), core area (CORE; mean core area of patch, excludes $90 \mathrm{~m}$ buffer from edge), cohesion (COHESION; connectivity of class type), edge density (ED; edge length of patch standardized by area), and the interspersion and juxtaposition index (IJI; class type intermixing). Additionally, for landscape descriptive statistics (Table 3), we calculated percentage of landscape (PLAND; proportional abundance of class type, standardized by area) and core percentage landscape (CPLAND; proportional abundance of class type core area, excludes $90 \mathrm{~m}$ buffer from edge) for each cover class.

We chose bird species if they scored as regionally important by Partners in Flight for the southeastern Coastal Plain region [17] (Table 2). We also included brown-headed cowbird, a nest parasite, and blue jay, a nest predator, because of their possible impact on declining species. Then, we averaged BBS counts for each species by year (i.e., mean of 3 years) and partial route, to calculate a species mean; we did not keep species with means below 0.20. Routes were categorized as low abundance for less than the mean and higher abundance for greater than or equal to the mean.

2.3. Statistical Analyses. We randomly used 37 partial routes for modeling, while reserving 15 partial routes for validation. Although there was little correlation, we removed one variable for each pair that was at least 70\% correlated (PROC CORR; SAS software, version 9.1, Cary, North Carolina, USA) based on the following order to retain: AREA, CORE, ED, COHESION, and IJI due to our interest in detecting species that may be vulnerable to areal loss. Then, for each species and extent, we selected the 5 best fitting, one to 4 variable models, using logistic regression with score selection (PROC LOGISTIC). We evaluated these candidate models with Akaike's Information Criteria corrected for small sample size $\left(\mathrm{AIC}_{\mathrm{c}}\right)$.

To assess model accuracy, we used all models within 2 $\mathrm{AIC}_{\mathrm{c}}$ units of the least $\mathrm{AIC}_{\mathrm{c}}$ value to predict lesser or greater abundance for 15 model validation routes (PROC LOGISTIC). We classified model fit as correct for a route if predicted probability was greater than or equal to $50 \%$ and bird abundance mean fell within the greater abundance category, or alternatively if probability was less than $50 \%$ and bird abundance mean was within the lesser abundance category. Final best model selection incorporated models with the greatest prediction rate from models that correctly predicted at least 11 out of 15 routes at each buffer extent. We removed models with more variables if there was a nested smaller model that predicted equally well at the same extent. Lastly, we used the SAS $c$ statistic, which measures model accuracy by the area under the curve (AUC) for a Receiver Operating Characteristic (ROC) curve at the 0.5 threshold, to determine how well the models fit all 52 routes, and we eliminated any models with a $c$ statistic below 0.80 .

To determine if model fit would increase by adjusting for spatial variability, we compared the final models for each species using GLIMMIX with and without a spatial covariance structure. For GLIMMIX covariance parameter estimates, we used estimates from a variogram for each model, using the residuals from PROC LOGISTIC.

\section{Results}

Five species had models that contained a mixture of positively associated area and edge variables (Table 1). Downy 
TABle 1: Avian models with $\mathrm{AIC}_{\mathrm{c}}$ value for modeling routes, prediction rate for validation routes, and $c$ statistic for all selected partial Breeding Bird Survey routes in Coastal Plain Georgia during 1995-1999.

\begin{tabular}{|c|c|c|c|c|c|}
\hline Species & Buffer $(\mathrm{km})$ & Best model $(\mathrm{s})^{\mathrm{ab}}$ & $\mathrm{AIC}_{\mathrm{c}}$ & Prediction rate & $c$ Statistic \\
\hline Acadian flycatcher & 2 & (+) HH-COHESION (-) CL-ED (+) MF-AREA & 37.74 & $11 / 15$ & 0.84 \\
\hline Blue jay & 4 & (-) HH-COHESION (-) CL-IJI (+) PH-ED (-) SH-ED & 32.55 & $11 / 15$ & 0.92 \\
\hline Brown-headed cowbird & 4 & (-) HH-ED (-) PH-AREA (+) LP-ED (-) LP-COHESION & 41.51 & $11 / 15$ & 0.83 \\
\hline Downy woodpecker & 4 & (+) CL-AREA (+) PH-ED (-) MF-IJI (+) SH-IJI & 35.04 & $12 / 15$ & 0.88 \\
\hline Field sparrow & 0.5 & (+) HW-IJI (-) CL-IJI (-) PH-ED (+) SH-IJI & 32.53 & $12 / 15$ & 0.93 \\
\hline Field sparrow & 0.5 & (+) HW-IJI (-) CL-IJI (+) SH-CORE (+) SH-IJI & 33.04 & $12 / 15$ & 0.91 \\
\hline Field sparrow & 0.5 & $(+) \mathrm{HW}-\mathrm{IJI}(+) \mathrm{HH}-\mathrm{IJI}(-) \mathrm{CL}-\mathrm{IJI}(+) \mathrm{SH}-\mathrm{CORE}$ & 33.60 & $12 / 15$ & 0.89 \\
\hline Field sparrow & 0.5 & (+) HW-IJI (-) CL-IJI (-) PH-ED (+) SH-CORE & 33.87 & $12 / 15$ & 0.91 \\
\hline Northern parula & 0.5 & (+) HH-ED (+) MF-AREA (-) SH-IJI & 38.18 & $11 / 15$ & 0.87 \\
\hline Northern parula & 1 & $(+) \mathrm{HH}-\mathrm{ED}(+) \mathrm{CL}-\mathrm{AREA}(+) \mathrm{MF}-\mathrm{AREA}$ & 40.67 & $12 / 15$ & 0.86 \\
\hline Northern parula & 2 & $(-)$ HW-AREA $(+)$ HH-ED (+) CL-AREA (+) MF-AREA & 34.29 & $13 / 15$ & 0.91 \\
\hline Northern parula & 2 & $(+) \mathrm{HH}-\mathrm{ED}(-) \mathrm{HH}$-AREA $(+)$ CL-AREA $(+)$ MF-AREA & 36.24 & $13 / 15$ & 0.91 \\
\hline Orchard oriole & 1 & (-) HW-IJI (+) HH-AREA (+) PH-ED (+) LP-CORE & 29.15 & $12 / 15$ & 0.88 \\
\hline Orchard oriole & 4 & (+) HH-ED (-) CL-IJI (+) PH-ED (+) PH-IJI & 38.23 & $12 / 15$ & 0.87 \\
\hline Pine warbler & 1 & (-) HH-IJI (-) HH-COHESION (-) MF-IJI (+) SH-IJI & 42.45 & $11 / 15$ & 0.83 \\
\hline Prairie warbler & 0.5 & $(+)$ HH-AREA $(-)$ MF-IJI (+) SH-ED & 25.31 & $12 / 15$ & 0.82 \\
\hline Red-bellied woodpecker & 4 & $(-)$ CL-IJI $(+)$ MF-IJI (+) LP-ED & 45.76 & $12 / 15$ & 0.80 \\
\hline Summer tanager & 1 & (-) CL-COHESION (+) PH-ED (+) LP-AREA (-) SH-IJI & 40.99 & $11 / 15$ & 0.86 \\
\hline Summer tanager & 2 & (-) HH-IJI (+) PH-ED (+) LP-AREA (-) LP-IJI & 33.52 & $11 / 15$ & 0.92 \\
\hline
\end{tabular}

${ }^{a}$ HW: hardwood forests; HH: hydric hardwoods; CL: clearcuts; PH: pasture/hay; MF: mixed forest; MP: managed pine; LP: longleaf pine; SH: shrub.

${ }^{b}$ AREA: mean patch area; COHESION: connectivity; CORE: mean core area; ED: edge length density; IJI: class type intermixing.

woodpecker greater abundance was associated positively with clearcut area and pasture edge density. Northern parula models combined positive variables of hydric hardwood edge density with mixed forest area at $0.5,1$, and $2 \mathrm{~km}$ extents along with clearcut area at 1 and $2 \mathrm{~km}$. Orchard oriole models consisted of positive variables that included pasture edge density at 1 and $4 \mathrm{~km}$, hydric hardwood edge density and area, and core area of longleaf pine. Prairie warbler models encompassed positive variables of hydric hardwood area and shrub edge. Summer tanager was linked to positive model variables of pasture edge density at 1,2 , and $4 \mathrm{~km}$ extents, longleaf pine area and edge density, and managed pine area.

Five species had models that did not contain a mixture of positive area and edge variables and involved only one model, and thus only one buffer extent (Table 1). Acadian flycatcher abundance was associated positively with mixed forest area. Field sparrow models included positive model variables of shrub core at multiple extents. Three species had models that contained edge density but not area variables. Blue jay was related positively to pasture edge density. Brownheaded cowbirds were associated positively with longleaf pine edge density. Red-bellied woodpecker model variables were related positively to longleaf pine edge density. Models for pine warbler did not have any positive area or edge variables.

Brown-headed nuthatch, brown thrasher, Carolina chickadee, Carolina wren, eastern kingbird, eastern towhee, eastern wood-pewee) indigo bunting, northern bobwhite, redheaded woodpecker, pileated woodpecker, white-eyed vireo, and wood thrush did not have any models that correctly predicted the minimum 11 out of 15 on the validation routes or did not meet the threshold 0.80 for $c$ statistic value.

For seven species, a spatial covariance structure did not produce better model fit. Prairie warbler and northern parula models improved with a spatial term, and for summer tanager, the models at 2 and $4 \mathrm{~km}$ improved with a spatial term. The field sparrow second and fourth models had greater fit with a spatial term.

\section{Discussion}

Even in the highly forested Coastal Plain core area, areal extent, edge density, and other landscape characteristics were important predictors of abundance for certain species, and the Coastal Plain may not provide enough continuous vegetation for area-sensitive species (Table 3 ). Despite the limited area sizes, area was still prevalent in models for most bird species. Area was a model variable for Acadian flycatcher, a species which may be area sensitive [18]. Field sparrow also appeared to respond to area, and they may avoid edges when interior dense vegetation is available [19], prefer to nest away from edge [20], or have reduced brood parasitism rates away from edge [21, 22]. Downy woodpecker, northern parula, orchard oriole, and summer tanager exhibited area as a model variable, which helps support positive area findings in previous studies [23, 24].

A mixture of area and edge variables developed in most models. One forest type adjacent to another forest type may 
Table 2: Common and scientific name, 2007 Southeastern Coastal Plain Partners in Flight conservation score, significant population trend during 1966-2005 for the Coastal Plain ${ }^{\mathrm{a}}$, and partial Breeding Bird Survey route mean abundance.

\begin{tabular}{|c|c|c|c|c|}
\hline Common name & Scientific name & Conservation score & Trend & Mean \\
\hline Acadian flycatcher & Empidonax virescens & 15 & + & 0.28 \\
\hline Blue jay & Cyanocitta cristata & 14 & - & 4.46 \\
\hline Brown thrasher & Toxostoma rufum & 15 & - & 1.57 \\
\hline Brown-headed cowbird & Molothrus ater & 8 & - & 1.29 \\
\hline Brown-headed nuthatch & Sitta pusilla & 20 & - & 0.20 \\
\hline Carolina chickadee & Poecile carolinensis & 16 & - & 0.92 \\
\hline Carolina wren & Thryothorus ludovicianus & 13 & 0 & 5.21 \\
\hline Downy woodpecker & Picoides pubescens & 14 & - & 0.42 \\
\hline Eastern kingbird & Tyrannus tyrannus & 15 & - & 1.38 \\
\hline Eastern towhee & Pipilo erythrophthalmus & 16 & - & 5.50 \\
\hline Eastern wood-pewee & Contopus virens & 14 & - & 0.44 \\
\hline Field sparrow & Spizella pusilla & 15 & - & 0.94 \\
\hline Indigo bunting & Passerina cyanea & 14 & 0 & 3.22 \\
\hline Northern bobwhite & Colinus virginianus & 16 & - & 3.62 \\
\hline Northern parula & Parula americana & 15 & 0 & 0.94 \\
\hline Orchard oriole & Icterus spurius & 16 & 0 & 0.80 \\
\hline Pileated woodpecker & Dryocopus pileatus & 14 & 0 & 0.51 \\
\hline Pine warbler & Dendroica pinus & 14 & + & 1.18 \\
\hline Prairie warbler & Dendroica discolor & 18 & - & 0.26 \\
\hline Red-bellied woodpecker & Melanerpes carolinus & 13 & 0 & 3.44 \\
\hline Red-headed woodpecker & $\begin{array}{c}\text { Melanerpes } \\
\text { erythrocephalus }\end{array}$ & 15 & 0 & 0.31 \\
\hline Summer tanager & Piranga rubra & 16 & 0 & 0.84 \\
\hline White-eyed vireo & Vireo griseus & 14 & 0 & 1.63 \\
\hline Wood thrush & Hylocichla mustelina & 15 & - & 0.72 \\
\hline
\end{tabular}

${ }^{a}$ Sauer et al. [14]. The North American Breeding Bird Survey, results and analysis 1966-2003. USGS Patuxent Wildlife Research Center, Laurel, Md, USA.

expand the functional area of each forest, and both edge and area would become important. Species associated with dense shrubby vegetation, which is characteristic of edges, may be more likely to respond to both edge and area. Alternatively, edge and area model combinations may reflect that scale and vegetation type influence area relationships. For example, a species could have, as a model variable, edge density linked with a vegetation type that the species avoids, if the edge represented lower abundance of the vegetation type. Occurrence of area and edge of the same vegetation type may show more clearly that the species is responding directly to the vegetation type, rather than the particular metric. Orchard oriole had models that included hydric hardwood area at $1 \mathrm{~km}$ and hydric hardwood edge density at $4 \mathrm{~km}$, whereas summer tanager models incorporated longleaf pine area at 1 and $2 \mathrm{~km}$ and longleaf pine edge density at $4 \mathrm{~km}$. However, these are separate models and thus could represent distinctive selection at different scales.

Brown-headed cowbirds were associated with their breeding habitat of an ecotone [25], specifically a longleaf pine edge, and away from larger grassy or woody extents. Perhaps longleaf pine edges provide a balance between breeding opportunities and access to feeding areas. Likewise, blue jay was linked to pasture edge density and thus may be a problem for birds nesting in ecotones.

The models did produce some interesting bird-vegetation type associations, compared to documented associations [26], some of which may provide new insight, and most may result from vegetation type classification error in the Gap land cover grid, bias in the BBS surveys, or spurious results from modeling. Clearcut areas, although a critical vegetation type, had an accuracy rate of only about $50 \%$ for the Gap land cover. The prairie warbler model did not contain clearcuts, rather hydric hardwoods and shrub, and the orchard oriole model also had hydric hardwoods, rather than open areas; this may indicate a Gap misclassification of clearcuts, and replacement of the hydric hardwoods vegetation type by clearcuts may correct these models. Northern parula had models containing clearcut area and forest edge. If the clearcut vegetation represents hardwoods, then the model is uncomplicated. Alternatively, northern parula use gaps, particularly after breeding [27], which might account for forest edge in the model, and to some extent, clearcuts if they represent small gaps. Field sparrow is associated with shrub/scrub [28], and although field sparrow models involved shrub area, the models also contain 
TABLE 3: Landscape summary metrics ${ }^{\mathrm{a}}$ of each class type for all selected partial Breeding Bird Survey routes in Coastal Plain Georgia during 1996-1998.

Hardwood forest Hydric hardwood Clearcut Pasture/hay Mixed forest Managed pine Longleaf pine Shrub

\begin{tabular}{|c|c|c|c|c|c|c|c|c|c|c|c|c|c|c|c|c|c|}
\hline Metric & $\begin{array}{c}\text { Buffer } \\
(\mathrm{km})\end{array}$ & 0 & SE & 0 & SE & 0 & SE & 0 & SE & 0 & SE & 0 & SE & 0 & SE & 0 & SE \\
\hline PLAND (\%) & 0.5 & 6.4 & 0.7 & 11.1 & 1.1 & 8.1 & 0.9 & 3.5 & 0.6 & 3.2 & 0.4 & 25.4 & 1.9 & 0.1 & 0.0 & 1.5 & 0.5 \\
\hline PLAND (\%) & 1 & 6.9 & 0.8 & 13.1 & 1.3 & 8.3 & 0.8 & 3.3 & 0.5 & 3.4 & 0.5 & 25.8 & 1.7 & 0.1 & 0.1 & 1.7 & 0.5 \\
\hline PLAND (\%) & 2 & 7.4 & 0.8 & 14.6 & 1.3 & 8.7 & 0.8 & 2.9 & 0.5 & 3.6 & 0.5 & 26.3 & 1.6 & 0.2 & 0.1 & 1.7 & 0.4 \\
\hline PLAND (\%) & 4 & 7.5 & 0.8 & 15.9 & 1.4 & 8.7 & 0.7 & 2.7 & 0.4 & 3.5 & 0.4 & 26.5 & 1.4 & 0.4 & 0.3 & 1.7 & 0.4 \\
\hline AREA (ha) & 0.5 & 0.4 & 0.0 & 0.9 & 0.1 & 0.9 & 0.1 & 1.0 & 0.2 & 0.3 & 0.0 & 2.4 & 0.3 & 0.2 & 0.1 & 0.8 & 0.1 \\
\hline AREA (ha) & 1 & 0.4 & 0.1 & 1.1 & 0.1 & 1.0 & 0.1 & 0.9 & 0.1 & 0.4 & 0.0 & 2.6 & 0.3 & 0.3 & 0.1 & 0.9 & 0.1 \\
\hline AREA (ha) & 2 & 0.5 & 0.1 & 1.3 & 0.1 & 1.1 & 0.1 & 1.0 & 0.1 & 0.4 & 0.0 & 2.7 & 0.3 & 1.0 & 0.4 & 1.0 & 0.1 \\
\hline AREA (ha) & 4 & 0.5 & 0.1 & 1.6 & 0.1 & 1.1 & 0.1 & 1.0 & 0.1 & 0.4 & 0.0 & 2.6 & 0.2 & 8.0 & 6.0 & 0.9 & 0.1 \\
\hline CORE (ha) & 0.5 & 0.0 & 0.0 & 0.0 & 0.0 & 0.0 & 0.0 & 0.1 & 0.1 & 0.0 & 0.0 & 0.3 & 0.1 & 0.0 & 0.0 & 0.0 & 0.0 \\
\hline CORE (ha) & 1 & 0.0 & 0.0 & 0.1 & 0.0 & 0.1 & 0.0 & 0.0 & 0.0 & 0.0 & 0.0 & 0.4 & 0.1 & 0.0 & 0.0 & 0.0 & 0.0 \\
\hline CORE (ha) & 2 & 0.0 & 0.0 & 0.1 & 0.0 & 0.1 & 0.0 & 0.0 & 0.0 & 0.0 & 0.0 & 0.4 & 0.1 & 0.0 & 0.0 & 0.0 & 0.0 \\
\hline CORE (ha) & 4 & 0.0 & 0.0 & 0.2 & 0.0 & 0.1 & 0.0 & 0.0 & 0.0 & 0.0 & 0.0 & 0.4 & 0.1 & 3.2 & 3.1 & 0.0 & 0.0 \\
\hline CPLAND (\%) & 0.5 & 0.0 & 0.0 & 0.3 & 0.1 & 0.4 & 0.1 & 0.1 & 0.0 & 0.0 & 0.0 & 2.5 & 0.4 & 0.0 & 0.0 & 0.1 & 0.1 \\
\hline CPLAND (\%) & 1 & 0.0 & 0.0 & 0.6 & 0.1 & 0.4 & 0.1 & 0.1 & 0.0 & 0.0 & 0.0 & 3.2 & 0.5 & 0.0 & 0.0 & 0.1 & 0.1 \\
\hline CPLAND (\%) & 2 & 0.0 & 0.0 & 0.9 & 0.2 & 0.5 & 0.1 & 0.1 & 0.0 & 0.0 & 0.0 & 3.4 & 0.4 & 0.0 & 0.0 & 0.1 & 0.1 \\
\hline CPLAND (\%) & 4 & 0.0 & 0.0 & 1.3 & 0.2 & 0.5 & 0.1 & 0.1 & 0.0 & 0.0 & 0.0 & 3.6 & 0.3 & 0.1 & 0.1 & 0.1 & 0.1 \\
\hline $\mathrm{ED}(\mathrm{m} / \mathrm{ha})$ & 0.5 & 47.3 & 3.5 & 56.8 & 4.8 & 39.8 & 3.5 & 26.1 & 3.6 & 26.1 & 3.0 & 76.7 & 4.1 & 2.9 & 1.6 & 8.4 & 1.8 \\
\hline $\mathrm{ED}(\mathrm{m} / \mathrm{ha})$ & 1 & 49.7 & 3.5 & 60.7 & 4.6 & 40.4 & 3.2 & 23.0 & 3.1 & 28.0 & 3.2 & 77.9 & 3.8 & 3.8 & 2.5 & 8.9 & 1.8 \\
\hline $\mathrm{ED}(\mathrm{m} / \mathrm{ha})$ & 2 & 51.9 & 3.7 & 63.4 & 4.5 & 41.1 & 3.1 & 19.9 & 2.6 & 28.6 & 3.2 & 79.1 & 3.6 & 4.3 & 2.7 & 8.6 & 1.6 \\
\hline $\mathrm{ED}(\mathrm{m} / \mathrm{ha})$ & 4 & 52.3 & 3.8 & 64.1 & 4.2 & 41.1 & 2.9 & 17.0 & 2.2 & 28.4 & 3.2 & 79.4 & 3.2 & 3.9 & 2.3 & 8.6 & 1.6 \\
\hline
\end{tabular}

aREA: mean patch area, CORE: mean core area, CPLAND: proportional abundance of class type core area, ED: edge length density, PLAND: proportional abundance of class type.

a negative association to pasture edge density, suggesting that field sparrows are not using edge as much as they are using either core area or else an abundance of pasture.

Scale affects which variables will be represented, and therefore scale choice is important. Each buffer extent included models for $3-5$ species, and 8 species only had models at one extent. For species with models at multiple extents, there was variable overlap among extents, which may reflect continuity in habitat selection. Also, in part scale differences may contribute to conflicting results in the literature about area sensitivity of some species.

Species that did not have models that met our criteria could be selecting sites based on different factors than modeled vegetation types or landscape metrics. Carolina chickadee, eastern towhee, northern bobwhite, and pine warbler may have area or edge requirements $[23,29,30]$, but modeling did not reflect these metrics. Stand scale elements, such as vegetation structure and composition including residual trees, may be particularly important for these species. Species that should be associated with a specific but rare vegetation type, such as brown-headed nuthatch and longleaf pine, may be using another vegetation type with appropriate structure [31]. For example, high density pine forests often lack a developed understory and pine forests without disturbance may contain a hardwood midstory rather than a herbaceous ground layer and shrubby understory, potentially limiting abundance of some species typically associated with opencanopy pine forests [32].

These models provide basic associations of bird species with vegetation type metrics in a region where relatively little is known about landscape relationships. Edge variables proved important for two species, blue jay and brownheaded cowbird, known to affect populations of some avian species through nest predation and parasitism, respectively. Area or a combination of area and edge is important for seven species of conservation concern, despite small areal extents and little core area in the Coastal Plain of Georgia. For other declining species, stand-scale metrics may be more critical, particularly when vegetation types are fragmented. Further research by modelers, field scientists and managers can contribute to understanding habitat that sustains avian populations.

Across a broader landscape, management that increases patch sizes of vegetation types may enhance habitat suitability for a large suite of species. Conversion to agriculture and large-scale timber harvesting in the nineteenth and early twentieth century affected much of the southern landscape, including Georgia [33]. Approximately 9.5\% of southeastern timberlands are publicly owned, in a patchwork of sizes and managed by various agencies [34]. Public land managers and private land owners, in collaboration, are in position to develop an appropriate mix of vegetation types and 
components across the landscape that optimizes biodiversity and addresses regional conservation concerns. Such a mix should include mature pine and hardwood forests, as well as early successional grasslands and shrublands. Present day forest management, with careful planning, can help coordinate development of continuous expanses of similar vegetation types while conserving low-contrast borders, to limit interior exposure to nest predators and parasites. Because there now are harvest size regulations, clearcut areas averaged 92 ha (20-600 ha) on commercial lands and 36 ha in public forests [35] in the past and more recent cut sizes ranged from about 16 to 32 ha [36]. The Sustainable Forestry Initiative requires the average size of cuts to not exceed 49 ha [37]. Nevertheless, large areas of similar stages can remain close through interspersion of harvests that are slightly offset in time; larger harvests and clustered cuts will retain more extensive areas of similar vegetation age, from regeneration to harvest stages, than multiple dispersed clearings.

\section{Acknowledgments}

This paper was funded by The National Council for Air and Stream Improvement, Inc., Federal Aid in Wildlife Restoration (Project W-48, Study 57), Mississippi Department of Wildlife, Fisheries and Parks, Weyerhaeuser Company, International Paper Company, MeadWestvaco Corporation, and Boise Cascade Corporation. Mississippi State University Department of Wildlife and Fisheries provided facilities. This is publication XXX of the Forest and Wildlife Research Center, Mississippi State University.

\section{References}

[1] W. C. Hunter, D. A. Buehler, R. A. Canterbury, J. L. Confer, and P. B. Hamel, "Conservation of disturbance-dependent birds in eastern North America," Wildlife Society Bulletin, vol. 29, no. 2, pp. 440-445, 2001.

[2] R. Sallabanks, J. R. Walters, and J. A. Collazo, "Breeding bird abundance in bottomland hardwood forests: habitat, edge, and patch size effects," Condor, vol. 102, no. 4, pp. 748-758, 2000.

[3] J. C. Turner, J. A. Gerwin, and R. A. Lancia, "Influences of hardwood stand area and adjacency on breeding birds in an intensively managed pine landscape," Forest Science, vol. 48, no. 2, pp. 323-330, 2002.

[4] D. G. Krementz and J. S. Christie, "Clearcut stand size and scrub-successional bird assemblages," Auk, vol. 117, no. 4, pp. 913-924, 2000.

[5] S. M. Aquilani and J. S. Brewer, "Area and edge effects on forest songbirds in a non-agricultural upland landscape in northern Mississippi, USA," Natural Areas Journal, vol. 24, no. 4, pp. 326-335, 2004.

[6] A. J. Weldon and N. M. Haddad, "The effects of patch shape on Indigo Buntings: evidence for an ecological trap," Ecology, vol. 86, no. 6, pp. 1422-1431, 2005.

[7] K. R. Hazler, A. J. Amacher, R. A. Lancia, and J. A. Gerwin, "Factors influencing Acadian flycatcher nesting success in an intensively managed forest landscape," Journal of Wildlife Management, vol. 70, no. 2, pp. 532-538, 2006.

[8] M. F. Hodges and D. G. Krementz, "Neotropical migratory breeding bird communities in riparian forests of different widths along the Altamaha River, Georgia," Wilson Bulletin, vol. 108, no. 3, pp. 496-506, 1996.

[9] J. C. Kilgo, R. A. Sargent, K. V. Miller, and B. R. Chapman, "Effect of stand width and adjacent habitat on breeding bird communities in Bottomland hardwoods," Journal of Wildlife Management, vol. 62, no. 1, pp. 72-83, 1998.

[10] J. A. Wiens, J. T. Rotenberry, and B. Van Horne, "Habitat occupancy patterns of North American shrubsteppe birds: the effects of spatial scale," Oikos, vol. 48, no. 2, pp. 132-147, 1987.

[11] G. H. Orians and J. F. Wittenberger, "Spatial and temporal scales in habitat selection," American Naturalist, vol. 137, pp. S29-S49, 1991.

[12] E. Kramer, M. J. Conroy, M. J. Elliott, E. A. Anderson, W. R. Bumback, and J. Epstein, The Georgia Gap Analysis Project: Final Report, University of Georgia Institute of Ecology, Athens, Ga, USA, 2003.

[13] R. C. Conner and A. J. Hartsell, "Forest area and conditions," in Southern Forest Resource Assessment, D. N. Wear and J. G. Greis, Eds., pp. 357-402, USDA Forest Service, Southern Research Station, Asheville, NC, USA, 2002.

[14] J. R. Sauer, J. E. Hines, and J. Fallon, The North American Breeding Bird Survey, Results and Analysis 1966-2003, USGS Patuxent Wildlife Research Center, Laurel, Md, USA, 2004.

[15] M. K. Trani, "Terrestrial ecosystems," in Southern Forest Resource Assessment, D. N. Wear and J. G. Greis, Eds., pp. 1-45, USDA Forest Service, Southern Research Station, Asheville, NC, USA, 2002.

[16] K. McGarigal, S. A. Cushman, M. C. Neel, and E. Ene, FRAGSTATS: Spatial Pattern Analysis Program for Categorical Maps, University of Massachusetts, Amherst, Mass, USA, 2002.

[17] A. O. Panjabi, E. H. Dunn, P. J. Blancher et al., "The Partners in Flight handbook on species assessment. Version 2005," Partners in Flight Technical Series 3, 2005, http:// www.rmbo.org/pubs/downloads/Handbook2005.pdf.

[18] D. R. Whitehead and T. Taylor, "Acadian flycatcher (Empidonax virescens)," in The Birds of North America, A. Poole and F. Gill, Eds., no. 614, The American Ornithologists' Union, Washington, DC, USA, 2002.

[19] A. D. Rodewald and A. C. Vitz, "Edge- and area-sensitivity of shrubland birds," Journal of Wildlife Management, vol. 69, no. 2, pp. 681-688, 2005.

[20] A. A. Woodward, A. D. Fink, and F. R. Thompson, "Edge effects and ecological traps: effects on shrubland birds in Missouri," Journal of Wildlife Management, vol. 65, no. 4, pp. 668-675, 2001.

[21] L. B. Best, "Field sparrow reproductive success and nesting ecology," Auk, vol. 95, pp. 9-22, 1978.

[22] J. E. Gates and L. W. Gysel, "Avian nest dispersion and fledging success in field-forest ecotones," Ecology, vol. 59, pp. 871-883, 1978.

[23] K. E. Freemark, J. B. Dunning, S. J. Hejl, and J. R. Probst, "A landscape ecology perspective for research, conservation, and management," in Ecology and Management of Neotropical Migratory Birds: A Synthesis and Review of Critical Issues, T. E. Martin and D. M. Finch, Eds., pp. 381-421, Oxford University Press, New York, NY, 1995.

[24] R. R. Moldenhauer and D. J. Regelski, "Northern parula (Parula americana)," in The Birds of North America, A. Poole and F. Gill, Eds., no. 215, The American Ornithologists' Union, Washington, DC, USA, 1996.

[25] P. E. Lowther, "Brown-headed cowbird (Molothrus ater)," in The Birds of North America, A. Poole and F. Gill, Eds., no. 47, Washington, DC, USA, The American Ornithologists' Union, 1993. 
[26] A. Poole and F. Gill, The Birds of North America, The American Ornithologists' Union, Washington, DC, USA, 2003.

[27] L. T. Bowen, C. E. Moorman, and J. C. Kilgo, "Seasonal bird use of canopy gaps in a bottomland forest," Wilson Journal of Ornithology, vol. 119, no. 1, pp. 77-88, 2007.

[28] M. Carey, D. E. Burhans, and D. A. Nelson, "Field sparrow (Spizella pusilla)," in The Birds of North America, A. Poole and F. Gill, Eds., no. 103, The American Ornithologists' Union, Washington, DC, USA, 1994.

[29] J. D. Groom and T. C. Grubb, "Patch colonization dynamics in Carolina Chickadees (Poecile carolinensis) in a fragmented landscape: a manipulative study," $A u k$, vol. 123, no. 4, pp. 1149-1160, 2006.

[30] P. G. Rodewald, J. H. Withgott, and K. G. Smith, "Pine warbler (Dendroica pinus)," in The Birds of North America, A. Poole and F. Gill, Eds., no. 438, The American Ornithologists' Union, Washington, DC, USA, 1999.

[31] M. D. Wilson and B. D. Watts, "Response of brown-headed nuthatches to thinning of pine plantations," Wilson Bulletin, vol. 111, no. 1, pp. 56-60, 1999.

[32] F. S. Gilliam and W. J. Platt, "Effects of long-term fire exclusion on tree species composition and stand structure in an oldgrowth Pinus palustris (Longleaf pine) forest," Plant Ecology, vol. 140, no. 1, pp. 15-26, 1999.

[33] M. Williams, Americans and Their Forests: A Historical Geography, Cambridge University Press, New York, NY, USA, 1989.

[34] USDA, The South's Fourth Forest: Alternatives for the Future, no. 24, Department of Agriculture, Forest Service, , Washington DC, USA, 1988.

[35] J. M. Meyers and A. S. Johnson, "Bird communities associated with succession and management of loblolly-shortleaf pine forests," in Proceedings of the Workshop Management of Southern Forests for Nongame Birds, R. M. DeGraaf, Ed., Forest Service General Technical Report SE-14, pp. 50-65, US Department of Agriculture, Forest Service, Washington, DC, USA, 1978.

[36] M. S. Woodrey, R. P. Ford, W. C. Hunter, and J. Taulman, East Gulf Coastal Plain Partners in Flight Bird Conservation Plan (physiographic area 4). Version 1.0, Mississippi Museum of Natural Science, Jackson, Miss, USA, 1998.

[37] Sustainable Forestry Initiative Inc, 2005-2009 Edition Sustainable Forestry Initiative (SFI) Program: 2005-2009 SFI Standard and Verification Procedures, The Sustainable Forestry Initiative program, Sustainable Forestry Board, and American Forest \& Paper Association, Washington, DC, USA, 2005. 

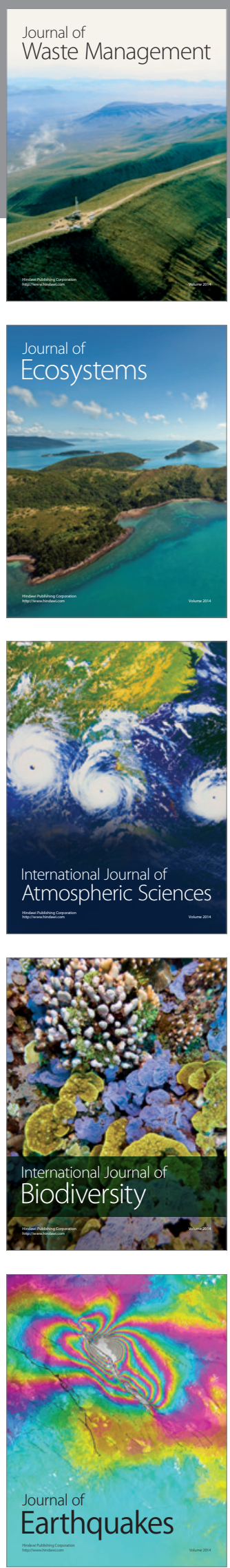
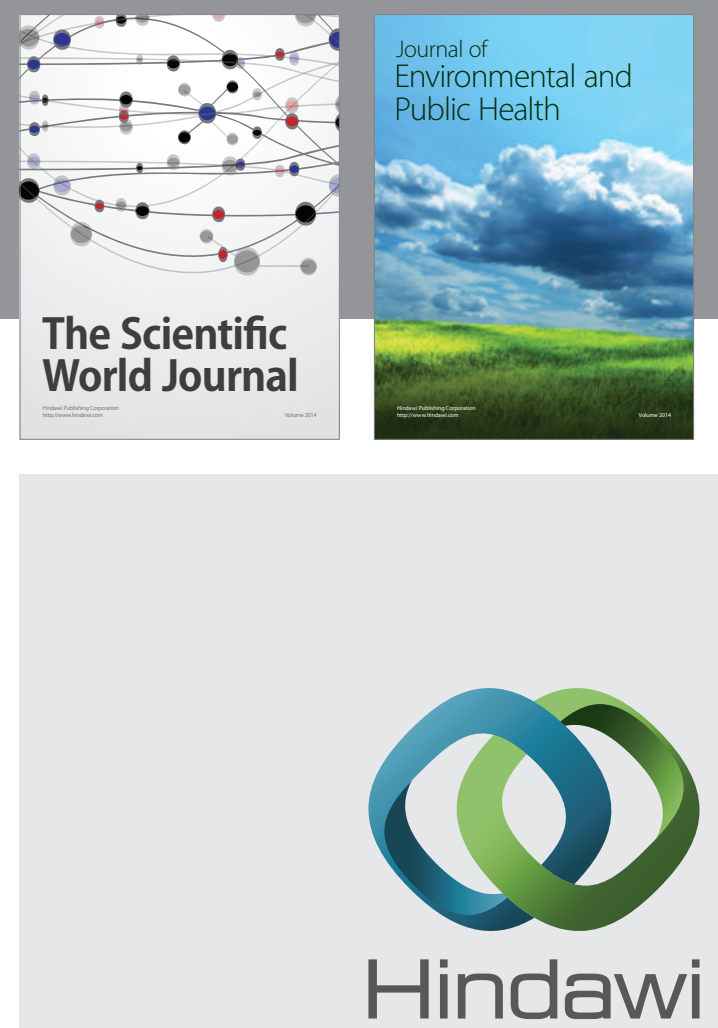

Submit your manuscripts at

http://www.hindawi.com
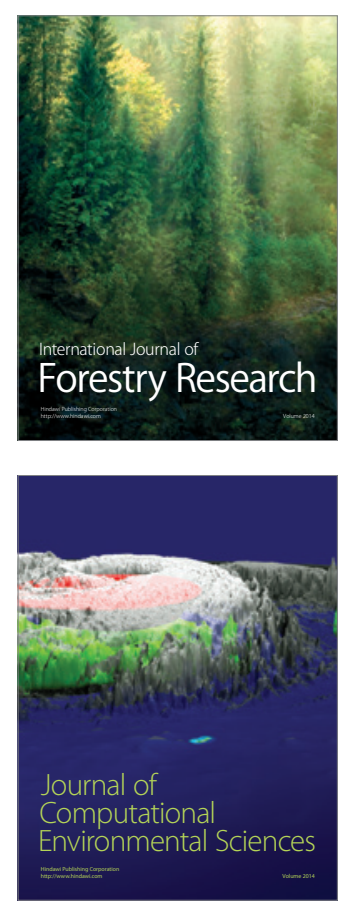
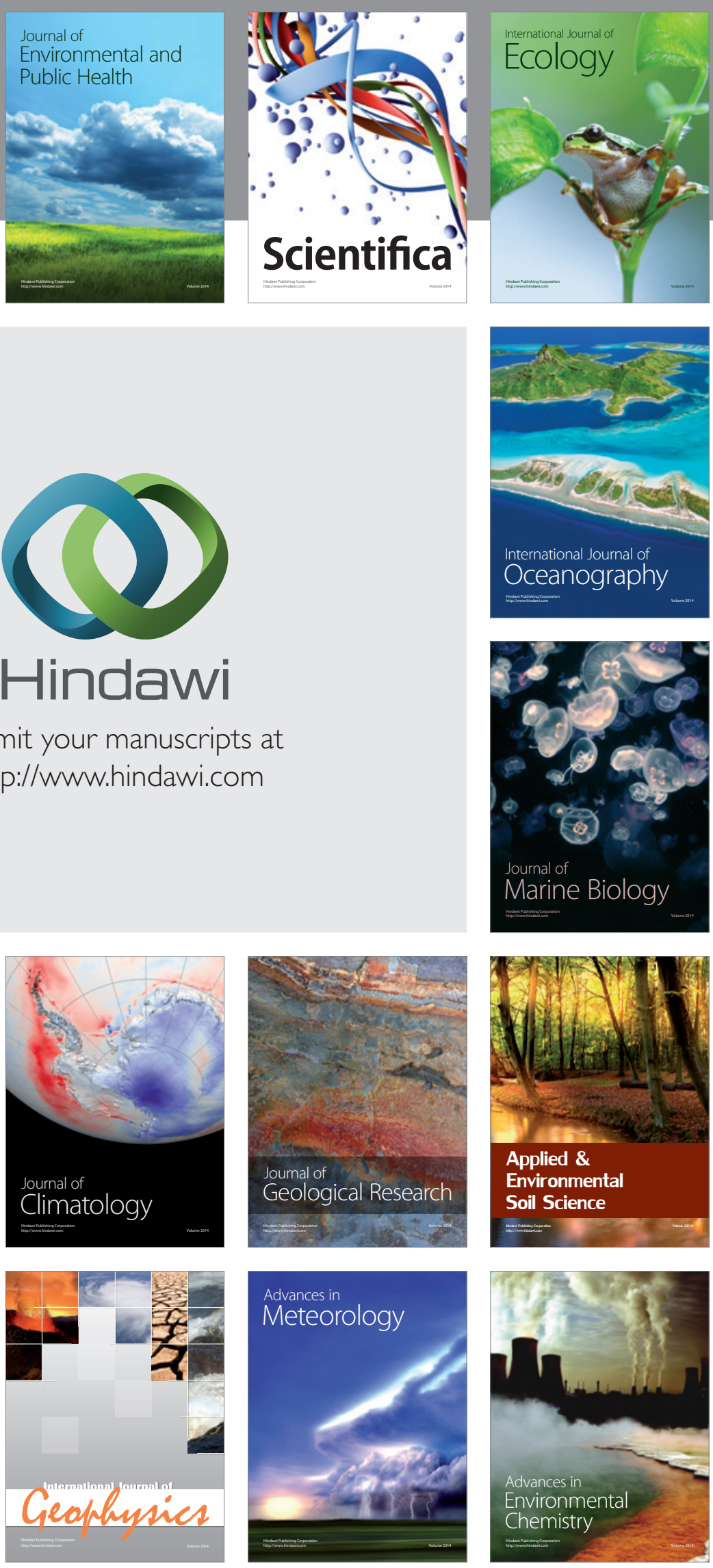